\title{
FAKTOR-FAKTOR YANG MEMPENGARUHI PRODUKSI PADI SRI
}

\section{System of Rice Intensification}

\author{
A Faroby Falatehan ${ }^{1)}$, Jamal Othman ${ }^{2)}$ \\ ${ }^{1)}$ Departemen Ekonomi Sumberdaya dan Lingkungan \\ Fakultas Ekonomi dan Manajemen, Institut Pertanian Bogor, Bogor, Indonesia \\ 2) Fakultas Ekonomi dan Manajemen \\ Universitas Kebangsaan Malaysia, Malaysia \\ Email:faroby@gmail.com
}

\begin{abstract}
The System of Rice Intensification (SRI) offers a number of advantages relative to theconventional system, the adoption of SRI among farmers in Indonesia is still very low. The objectives of this study are to analyze factors impact of SRI production. This study surveyed some 360 paddy farmer-respondents in the largest rice producer area in West Java - Subang and Karawang. Respondents were classified into SRI and non-SRI farmers. The survey was conducted during October 2012 to March 2013. The study found that the production function analysis found that dummy SRI has significant roles in augmenting production for SRI farmers, but all of SRI production factors are not significant. Both SRI and non SRI exhibit decreasing returns to scale in production technology. This implies that both systems demonstrate decreasing average cost in the long-run. The findings from the study are used as a basis for the formulation of policies and agricultural development of SRI in Indonesia.
\end{abstract}

Keywords: SRI, System of Rice Intensification, paddy, rice, dummy variable

\begin{abstract}
ABSTRAK
Sistem Intensifikasi Padi (SRI) menawarkan sejumlah keunggulan dibandingkan sistem konvensional, penerapan SRI di kalangan petani di Indonesia masih sangat rendah.Tujuan dari penelitian ini adalah untuk menganalisis faktor-faktor yang mempengaruhi produksi SRI. Penelitian ini mensurvei sekitar 360 petani padi di daerah penghasil padi terbesar di Jawa Barat,yaitu Subang dan Karawang. Responden dikelompokkan menjadi petani SRI dan nonSRI.Hasil studi menemukan bahwa analisis fungsi produksi menunjukkan bahwa variabel dummySRI memiliki peran penting dalam meningkatkan produksi bagi petani SRI, namun semua faktor produksi SRI tidak signifikan. Baik SRI maupun non SRI menunjukkan penurunan hasil pada skala teknologi produksi. Ini menyiratkan bahwa kedua sistem menunjukkan penurunan biaya rata-rata dalam jangka panjang.Temuan dari penelitian ini digunakan sebagai dasar perumusan kebijakan dan pengembangan pertanian SRI di Indonesia.
\end{abstract}

Kata kunci: SRI, Sistem Intensifikasi Padi, padi, beras, variabel dummy 


\section{PENDAHULUAN}

\section{Latar Belakang}

Penggunaan input dalam proses produksi dan penggunaan teknologi berperan penting dalam pembangunan pertanian. Tahun 1963, Pemerintah Indonesia telah membuat suatu kebijakan untuk meningkatkan produksi padi, yaitu melalui program Panca Usahatani. Program Panca Usahatani terdiri dari pengolahan tanah, pemberian pupuk kimia, perbaikan saluran pengairan, penanaman bebit unggul, serta pengendalian hamadan penyakit dengan pestisida. Teknologi ini menggunkaanteknik pertanian intensif melalui pemakaian pestisida dan pupukkimia.Dengan adanya teknologi ini diharapkan keperluan bahan panganyang setiap tahun selalu meningkat dapat terpenuhi. Program Panca Usahatani telah meningkatkan produksipadi Indonesia.Indonesia menjadi negara swasembada beras pada tahun 1983 hingga 1984.

Saat ini telah banyak dikembangkan pertanian alternative, salah satunya adalah pertanian organik.Konsep pertanian organik dianggap mampu meningkatkan kemandirian petani dalam usahanya karena memanfaatkan masukan produksi dari sekitaran (berbasis pada kebijaksanaan tempatan).Salah satunya adalah konsep pertanian metode SRI (System of Rice Intensification).

SRI di Indonesia telah dikembangkan di banyak daerah, seperti Jawa Barat, Yogyakarta, Sulawesi, NTB, dan NTT. Dari beberapa laporan percobaan pola SRI di beberapa daerah tersebut, menunjukkan bahwa produksi padi SRI dapat mencapai 7 hingga 10 ton/ha. Jika dibandingkan dengan pola penanaman konvensional, hasil ini adalah lebih tinggi.

\section{Rumusan Masalah}

SRI merupakan salah satu alternatif teknologi pertanian yang dilakukan oleh petani di Indonesia, seperti di Kabupaten Karawang dan Kabupaten Subang. Kedua kabupaten ini merupakan daerah penghasil beras terbesar di Jawa Barat. Pelaksanaan SRI di wilayah ini sudah dimulaisecara resmi pada tahun 2010

Dalam melakukan proses produksi, kurang tepatnya penggunaan teknologi akan mengakibatkan produksi yang rendah dan biaya yang tinggi. Dalam penggunaan teknologi atau input secara optimum perlu diketahui input mana saja yang harus ditambah dan dikurangi. Oleh karena itu penelitian ini menganalisis faktor-faktor pa saja yang mempengaruhi pola produksi antara SRI dan non SRI.

\section{Tujuan Penelitian}

Tujuan penelitian ini adalah untuk mengetahui faktor-faktor apa saja yang memperngaruhi produksi padi SRI dan non SRI di Jawa Barat, khususnya di Kabpaten Karawang dan Kabupaten Subang.

\section{KAJIAN PUSTAKA}

\section{Sistem Intensifikasi Padi (SRI)}

SRI pertama kali diperkenalkan oleh seorang pendeta dan beberapa orang petani di Madagaskar. Menjelang akhir tahun 1990-an, SRI mulai menerima pengakuan dunia berkat usaha gigih Prof. Dr. Norman Uphoff, mantan Direktur Cornell International Institute of Food, Agriculture and Development (CIIFAD), Cornell University, Amerika Serikat. Prinsip dasar dari SRI ini adalah menggunakan bibit padi, menggunakan ruang yang luas dengan anak padi tunggal, mempertahankan air agar tidak mengalir, memperbanyak bahan organik tanah dan menjaga pengaliran tanah sebaik mungkin.

Mutakin, 2007, menyatakan bahwa SRI adalah sistem penanaman padi yang mampu meningkatkan produktivitas tanaman dengan cara mengubah pengendalian tanaman, tanah, air dan nutrisinya. SRI juga dapat meningkatkan efisiensi penggunaan benih sehingga 20 persen, penurunan sehingga 50 persen penggunaan pupuk kimia, dan penhematan penggunaan air sehingga 40 persen, dan dalam segi produktivitas, SRI dapat meningkatkan produktivitas sehingga 50 persen. Walaupun kaedah SRI dikatakan mempunyai banyak kelebihan, penggunaan SRI di beberapa lokasi di Indonesia menghasilkan produksi yang berbeda. Di beberapa kawasan, SRI telah dianggap gagal, dengan pengeluaran yang tidak terlalu baik jika dibandingkan dengan cara konvensional (Darmawan dan Astiana, 2007).

Jumlah petani yang melakukan SRI sejak tahun 2010 belum mencapai 200 ribu petani. Jumlah ini sangat sedikit jika dibandingkan dengan sasaran yang ditetapkan oleh Kementerian Pertanian, diharapkan pada tahun 2020 jumlah petani yang mengamalkan SRI dapat mencecah 2 juta orang.

\section{METODE PENELITIAN}

\section{Metode Pengambilan Sampel Dan Pengumpulan Data}

Data yang digunakan dalam kajian ini adalah data primer dan data sekunder.Data primer diperoleh melalui wawancara dengan panduan kuisioner yang telah dipersiapkan untuk petani padi sawah yang 
menjadi responden.Sedangkan data sekunder didapat dari data yang didapat dari berbagai sumber.

Dalam kajian ini yang dimaksud dengan petani sampel adalah petani padi SRI dan non SRI sebagai unit analisis. Petani SRI adalah petani melakukan program penanaman yang sesuai dengan pola SRI. Petani non SRI adalah petani yang melakukan pola penanaman secara konvensional. Jumlah total responden adalah 360 petani, dari masing-masing kecamatan adalah 60 orang yang terdiri dari 30 orang petani yang melakukan penanaman pola SRI dan 30 orang yang tidak melakukan penanaman pola SRI.

Survei di lapangan, di Kabupaten Karawang dan Kabupaten Subang dilakukan dari bulan Oktober 2012 hingga Maret 2013. Data sekunder dikumpulkan dari berbagai lembaga yang berhubungan dengan kajian baik di tingkat pusat (Badan Pusat Statistik/BPS, Direktorat Jenderal Hortikultura, Badan Kajian dan Pengembangan Pertanian, Pusat Kajian dan Pengembangan Hortikultura, Pusat Analisis Sosial Ekonomi dan Kebijakan Pertanian, Balai Besar Sumberdaya dan Lahan) maupun Kawasan.

\section{Analisis Regresi}

\section{a. Model Persamaan}

Analisis data menggunakan model regresi linear dengan menggunakan variable dalam satuan per hektar. Model-model persamaan memiliki beberapa variabeldummy, yaitu dummy untuk Kabupaten Karawang, lokasi ketinggian dan SRI. Berikut ialah persamaan fungsi pengeluaran:

$$
\begin{aligned}
\mathrm{PD}_{\mathrm{i}}= & \mathrm{c}_{0}+\mathrm{c}_{1} \mathrm{DK}+\mathrm{c}_{2} \mathrm{DS}+\mathrm{c}_{3} \text { DKDS }+\mathrm{c}_{4} \mathrm{D} 1+ \\
& \mathrm{c}_{5} \mathrm{D} 2+\mathrm{c}_{6} \mathrm{UR}_{\mathrm{i}}+7 \mathrm{TSP}_{\mathrm{i}}+\mathrm{c}_{8} \mathrm{NPK}_{\mathrm{i}}+ \\
& \mathrm{c}_{9} \mathrm{HAI}_{\mathrm{i}}+\mathrm{c}_{10} \mathrm{RAC}_{\mathrm{i}}+\mathrm{c}_{11} \mathrm{TK}_{\mathrm{i}}+ \\
& \mathrm{c}_{12} \mathrm{URDS}_{\mathrm{i}}+\mathrm{c}_{13} \mathrm{TSPDS}_{\mathrm{i}}+ \\
& \mathrm{c}_{14} \mathrm{NPKDS}_{\mathrm{i}}+\mathrm{c}_{15} \mathrm{HAIDS}_{\mathrm{i}}+\mathrm{c}_{16} \mathrm{TKDS}_{\mathrm{i}}+ \\
& \mathrm{c}_{17} \text { D1DS }+\mathrm{c}_{18} \text { D2DS }+\mu \ldots \text { (1) }
\end{aligned}
$$

\begin{tabular}{|c|c|c|}
\hline $\mathrm{PD}_{\mathrm{i}}$ & : & jumlah produksi padi per hektar(ton/hektar) \\
\hline DK & : & $\begin{array}{l}\text { dummyKabupaten Karawang } \\
\text { (1= Kabupaten Karawang, 0=lainnya) }\end{array}$ \\
\hline DS & : & dummySRI (1=SRI, 0=lainnya) \\
\hline DKDS & : & $\begin{array}{l}\text { dummyinteraksi antara dummykabupaten dan } \\
\text { dummySRI }\end{array}$ \\
\hline D1 & : & $\begin{array}{l}\text { dummykawasan tengah } \\
(1=\text { kawasan tengah, } 0=\text { lainnya })\end{array}$ \\
\hline D2 & : & $\begin{array}{l}\text { dummykawasan rendah } \\
(1=\text { kawasan rendah, } 0=\text { lainnya })\end{array}$ \\
\hline $\mathrm{UR}_{\mathrm{i}}$ & : & jumlah pupuk urea per hektar (kg/hektar) \\
\hline $\mathrm{TSP}_{\mathrm{i}}$ & : & jumlah pupuk TSP per hektar(kg/hektar) \\
\hline $\mathrm{NPK}_{\mathrm{i}}$ & : & jumlah pupuk NPKper hektar(kg/hektar) \\
\hline $\mathrm{HAI}_{\mathrm{i}}$ & : & jumlah pupukkandang per hektar(kg/hektar) \\
\hline $\mathrm{RAC}_{\mathrm{i}}$ & . & biaya pestisida per hektar(Rp/hektar) \\
\hline
\end{tabular}

\begin{tabular}{|c|c|c|}
\hline $\mathrm{TK}_{\mathrm{i}}$ & : & $\begin{array}{l}\text { jumlah penggunaan tenaga kerja per hektar } \\
\text { (hari orang kerja (HOK)/hektar) }\end{array}$ \\
\hline $\mathrm{URDS}_{\mathrm{i}}$ & : & $\begin{array}{l}\text { interaksi antara jumlah urea per hektar } \\
\text { dan dummySRI }\end{array}$ \\
\hline TSPDS $_{\mathrm{i}}$ & : & $\begin{array}{l}\text { interaksi antara jumlah TSP per hektar } \\
\text { dan dummySRI }\end{array}$ \\
\hline NPKDS $_{i}$ & : & $\begin{array}{l}\text { interaksi antara jumlah NPK per hektar } \\
\text { dan dummySRI }\end{array}$ \\
\hline HAIDS $_{\mathrm{i}}$ & : & $\begin{array}{l}\text { interaksi antara jumlah baja kotoran haiwan } \\
\text { per hektar dan dummySRI }\end{array}$ \\
\hline TKDS $_{\mathrm{i}}$ & : & $\begin{array}{l}\text { interaksi antara jumlah penggunaan tenaga kerja } \\
\text { per hektar dan dummySRI }\end{array}$ \\
\hline D1DS & : & $\begin{array}{l}\text { interaksi antara dummykawasan tengah dan } \\
\text { dummySRI }\end{array}$ \\
\hline D2DS & . & $\begin{array}{l}\text { interaksi antara dummykawasan rendah dan } \\
\text { dummySRI }\end{array}$ \\
\hline
\end{tabular}

Hipotesis awal:

$$
\begin{gathered}
\mathrm{C}_{1}, \mathrm{C}_{2}, \mathrm{C}_{3}, \mathrm{C}_{4}, \mathrm{C}_{5}, \mathrm{C}_{6}, \mathrm{C}_{7}, \mathrm{C}_{8}, \mathrm{C}_{9}, \mathrm{C}_{10}, \mathrm{C}_{11}, \mathrm{C}_{12}, \mathrm{C}_{13}, \\
\mathrm{C}_{14}, \mathrm{C}_{15}, \mathrm{C}_{16}, \mathrm{C}_{17}, \mathrm{C}_{18}>0
\end{gathered}
$$

\section{b. Penilaian Model}

Evaluasi model pendugaan bertujuan untuk mengetahui apakah model yang diduga terpenuhi secara teori ekonomi dan statistik.Untuk itu kriteria pemilihan model terbaik dalam analisis regresi linier berganda harus sesuaidengan kriteria ekonomi, statistic dan ekonometrik.Kriteria Ekonomi, kriteria ini berupa penentuan parameter model persamaan regresi yang digunakan berdasarkan teori ekonomi yang ada, kemudian diuji berdasarkan teori ekonomi.Teori ekonomi yang digunakan untuk menerangkan hasil analisis ini adalah teori fungsi produksi. Kriteria Statistik, ini untuk menguji pengaruh parameter secara individu, pengujian parameter secara keseluruhan, dan koefisien determinasi $\left(\mathrm{R}^{2}\right)$ sebagai suatu ukuran goodness of fit dan statistik uji yang digunakan untuk mengukur signifikan parameter secara individu yaitu ujian t, sedangkan secara keseluruhan adalah ujian F.Kriteria Ekonometrika, pada kriteria ini andaian utama yang harus dipenuhi adalahKenormalan, Homoskedastisitas, Multikolinearitas, dam Autokorelasi.

\section{HASIL DAN PEMBAHASAN}

Beberapa variabel yang digunakan dalam model diantaranyavariabeldummy interaksi dengan dummy SRI. Beberapa variabel yang digunakan dalam model yaitu jumlah output padi per hektar, dummy Kabupaten Karawang, dummy SRI, dummy interaksi antara dummy kabupaten dan dummy SRI, dummy kawasan tengah, dummy kawasan rendah, jumlah pupuk urea per hektar, jumlah pupuk TSP per hektar, jumlah pupuk NPK per hektar, jumlah pupukkandangper hektar, biayapestisidaper hektar, jumlah penggunaan tenaga kerja per hektar, interaksi antara jumlah urea per hektar dan dummy SRI, interaksi antara jumlah TSP per hektar dan 
dummy SRI, interaksi antara jumlah NPK per hektar dan dummy SRI, interaksi antara jumlah pupukkandang per hektar dan dummy SRI dan interaksi antara jumlah penggunaan tenaga kerja per hektar dan dummy SRI.

Tabel1 memperlihatkan rata-rata variabel dari fungsi produksi yang digunakan. Rata-rata produksi output per hektar adalah 5.976 kg/hektar. Rata-rata untuk input pupuk kimia, seperti pupuk urea pada seluruh pertanian ialah $234 \mathrm{~kg}$ per hektar, sedangkan untuk TSP sebesar $121 \mathrm{~kg}$ per hektar dan NPK ialah $140 \mathrm{~kg}$ per hektar. Penggunaan pupuk kandang secara rata-rata ialah $908 \mathrm{~kg}$ per hektar, serta biaya untuk pupuk ialah Rp 427.526 per hektar.

Tabel 1. Rata-rataVariabel Input pada Fungsi Produksi $(\mathrm{N}=360)$

\begin{tabular}{|c|c|c|c|c|c|}
\hline & & Variabel & $\begin{array}{c}\text { Rata- } \\
\text { rata }\end{array}$ & Satuan & Std. Error \\
\hline $\mathrm{PD}_{\mathrm{i}}$ & : & $\begin{array}{l}\text { Jumlah Produksi } \\
\text { Padi per hektar }\end{array}$ & 5.976 & $\begin{array}{r}(\mathrm{kg} / \\
\text { hektar) }\end{array}$ & 1220,05 \\
\hline $\mathrm{UR}_{\mathrm{i}}$ & : & $\begin{array}{l}\text { Jumlah pupuk Urea } \\
\text { per hektar }\end{array}$ & 234 & $\begin{array}{r}(\mathrm{kg} / \\
\text { hektar) }\end{array}$ & 163,38 \\
\hline $\mathrm{TSP}_{\mathrm{i}}$ & : & $\begin{array}{l}\text { Jumlah pupuk } \\
\text { TSPper hektar }\end{array}$ & 121 & $\begin{array}{r}(\mathrm{kg} / \\
\text { hektar) }\end{array}$ & 125,00 \\
\hline $\begin{array}{l}\text { NPK } \\
i\end{array}$ & : & $\begin{array}{l}\text { Jumlah pupuk NPK } \\
\text { per hektar }\end{array}$ & 140 & $\begin{array}{r}(\mathrm{kg} / \\
\text { hektar) }\end{array}$ & 124,01 \\
\hline $\mathrm{HAI}_{\mathrm{i}}$ & : & $\begin{array}{l}\text { Jumlah } \\
\text { pupukkandangper } \\
\text { hektar }\end{array}$ & 908 & $\begin{array}{r}(\mathrm{kg} / \\
\text { hektar) }\end{array}$ & 883,18 \\
\hline $\begin{array}{l}\text { RAC } \\
\mathrm{i}\end{array}$ & : & $\begin{array}{l}\text { Biayapestisidaper } \\
\text { hektar }\end{array}$ & 427.526 & $\begin{array}{r}(\mathrm{Rp} / \\
\text { hektar) }\end{array}$ & $270.987,61$ \\
\hline $\mathrm{TK}_{\mathrm{i}}$ & : & $\begin{array}{lll}\text { Jumlah } & \text { penggunaan } \\
\text { tenaga } & \text { kerja } & \text { per } \\
\text { hektar } & & \end{array}$ & 160 & $\begin{array}{l}(\mathrm{HOK} / \mathrm{h} \\
\text { ektar })\end{array}$ & 43,09 \\
\hline $\begin{array}{l}\text { URD } \\
S_{i}\end{array}$ & : & $\begin{array}{l}\text { Interaksi antara } \\
\text { jumlah urea per } \\
\text { hektar dengan } \\
\text { dummySRI }\end{array}$ & 82 & $\begin{array}{r}(\mathrm{kg} / \\
\text { hektar) }\end{array}$ & 129,18 \\
\hline $\begin{array}{l}\text { TSP } \\
\mathrm{DS}_{\mathrm{i}}\end{array}$ & : & $\begin{array}{l}\text { Interaksi antara } \\
\text { jumlah TSP per } \\
\text { hektar dengan } \\
\text { dummySRI }\end{array}$ & 47 & $\begin{array}{r}(\mathrm{kg} / \\
\text { hektar) }\end{array}$ & 100,08 \\
\hline $\begin{array}{l}\text { NPK } \\
\text { DS }_{i}\end{array}$ & : & $\begin{array}{l}\text { Interaksi antara } \\
\text { jumlah NPK per } \\
\text { hektar dengan } \\
\text { dummySRI }\end{array}$ & 61 & $\begin{array}{r}(\mathrm{kg} / \\
\text { hektar) }\end{array}$ & 100,97 \\
\hline $\begin{array}{l}\mathrm{HAI} \\
\mathrm{DS}_{\mathrm{i}}\end{array}$ & : & $\begin{array}{l}\text { Interaksi antara } \\
\text { jumlah } \\
\text { pupukkandang per } \\
\text { hektar dengan } \\
\text { dummySRI }\end{array}$ & 677 & $\begin{array}{r}(\mathrm{kg} / \\
\text { hektar) }\end{array}$ & 995,94 \\
\hline $\begin{array}{l}\text { RAC } \\
\mathrm{DS}_{\mathrm{i}}\end{array}$ & : & $\begin{array}{ll}\text { Interaksi } & \text { antara } \\
\text { biayapestisidaper } \\
\text { hektar } & \text { dengan } \\
\text { dummySRI } & \end{array}$ & 171.747 & $\begin{array}{r}(\mathrm{Rp} / \\
\text { hektar) }\end{array}$ & $211,837,98$ \\
\hline $\begin{array}{l}\text { TKD } \\
S_{i}\end{array}$ & : & $\begin{array}{l}\text { Interaksi antara } \\
\text { jumlah penggunaan } \\
\text { tenaga kerja per } \\
\text { hektar dengan } \\
\text { dummySRI }\end{array}$ & 83 & $\begin{array}{l}(\mathrm{HOK} / \mathrm{h} \\
\text { ektar })\end{array}$ & 91,36 \\
\hline
\end{tabular}

Tabel 1 menggambarkan hasil estimasi fungsi produksi untuk model 1. Model ini memiliki nilai $F$ yang signifikan pada taraf nyata 1 persen, ini berarti bahwa model sudah baik. Nilai koefisien determinasi $\left(\mathrm{R}^{2}\right)$ untuk SRI adalah 40 persen, yang berarti bahwa 40 persen faktor-faktor yang mempengaruhi produksi padi dipengaruhi oleh variabel-variabel yang ada pada persamaan, sedangkan 60 persen lainnya dipengaruhi oleh faktor lain diluar persamaan.

Model 1 memperlihatkan bahwa pada persamaan tersebut terdapat variabel yang memiliki nilai VIF lebih dari 10, dan CI lebih dari 30, ini berarti terdapat multikolinearitas. Variabel yang memiliki nilai VIF lebih dari 10 ialah untuk variable dummy SRI, jumlah pupuk kandang per hektar, dummy interaksi antara jumlah pupuk kandang per hektar dan dummy SRI dan dummy interaksi antara tenaga kerja per hektar dan Dummy SRI. Nilai Durbin Watson sebesar 1.71, ini berarti tidak terdapat autokorelasi, karena berada pada range 1.54 hingga 2.46 .

Tabel 2. Hasil Estimasi Model 1 untuk SRI dan Non SRI

\begin{tabular}{|c|c|c|c|}
\hline Variabel & Koefisien & Std. Error & $\begin{array}{l}\text { VIF } \\
\end{array}$ \\
\hline $\bar{C}$ & 5001,10 & 527,54 & \\
\hline DK & $-568,67$ & $188,83^{\mathrm{a}}$ & 3,39 \\
\hline DS & 960,14 & 617,10 & 36,24 \\
\hline D1 & $-407,26$ & $222,91^{\text {a }}$ & 4,20 \\
\hline D2 & 131,33 & 198,70 & 3,34 \\
\hline D1DS & 666,74 & $290,46^{\mathrm{a}}$ & 4,46 \\
\hline D2DS & $-32,64$ & 298,08 & 4,70 \\
\hline DKDS & 588,42 & $271,11^{\mathrm{a}}$ & 5,25 \\
\hline UR & $-0,52$ & 0,55 & 3,08 \\
\hline TSP & 1,86 & $0,82^{\mathrm{a}}$ & 4,09 \\
\hline NPK & 1,53 & $0,69^{\mathrm{a}}$ & 2,81 \\
\hline HAI & $-0,13$ & 0,26 & 19,99 \\
\hline RAC & 0,00 & 0,00 & 2,03 \\
\hline TK & 2,26 & 3,05 & 6,54 \\
\hline URDS & 0,01 & 0,90 & 5,08 \\
\hline TSPDS & $-1,58$ & 1,19 & 5,37 \\
\hline NPKDS & $-1,01$ & 1,08 & 4,48 \\
\hline HAIDS & 0,09 & 0,28 & 28,86 \\
\hline RACDS & 0,00 & 0,00 & 4,69 \\
\hline TKDS & 1,41 & 3,41 & 36,83 \\
\hline F & 11,84 & $0,00^{\mathrm{a}}$ & \\
\hline R2 & 0,40 & & \\
\hline DW & 1,71 & & \\
\hline CI & 57,77 & & \\
\hline
\end{tabular}


Keterangan:

a: signifikan pada taraf uji $1 \%$

b: signifikan pada taraf uji $5 \%$

c: signifikan pada taraf uji $10 \%$

Oleh karena Model 1 terjadi multikolinearitas, maka dilakukan estimasi lebih lanjut. Tabel3 memperlihatkan Model 2, dimana model tersebut sudah tidak terdapat multikolinearitas. Model ini memiliki nilai $\mathrm{F}$ yang signifikan pada taraf nyata 1 persen, ini berartibahwa model sudah baik. Nilai koefisien determinasi $\left(\mathrm{R}^{2}\right) 40$ persen, yang berartibahwa 40 persen faktor-faktor yang mempengaruhi produksi padi dipengaruhi oleh variabel-variabel yang ada pada persamaan, sedangkan 60 persen lainnya dipengaruhi oleh faktor lain diluar persamaan. Nilai Durbin Watson sebesar 1,71, ini berarti tidak terdapat autokorelasi, karena berada pada range 1,54 hingga 2,46. Persamaan ini memiliki nilai CI yang kurang dari 30 , yaitu21,43. Selain itu nilai VIF tidak ada yang lebih dari 10, ini berarti tidak terdapat multikolinearitas.

Tabel 3. Hasil Estimasi Model 2 untuk SRI dan Non SRI

\begin{tabular}{|c|c|c|c|}
\hline Variabel & Koefisien & Std. Error & VIF \\
\hline $\mathrm{C}$ & 4771,10 & 296,71 & \\
\hline DK & $-526,57$ & $172,01^{\mathrm{a}}$ & 2,84 \\
\hline DS & 1261,91 & $275,05^{\mathrm{a}}$ & 7,26 \\
\hline D1 & $-366,45$ & $206,50^{\mathrm{a}}$ & 3,64 \\
\hline D2 & 158,57 & 188,22 & 3,02 \\
\hline DKDS & 541,79 & $252,56^{\mathrm{a}}$ & 4,59 \\
\hline D1DS & 619,06 & $274,41^{\mathrm{a}}$ & 4,01 \\
\hline D2DS & $-54,71$ & 288,19 & 4,43 \\
\hline UR & $-0,55$ & 0,54 & 2,94 \\
\hline TSP & 1,80 & $0,82^{\mathrm{a}}$ & 4,03 \\
\hline NPK & 1,45 & $0,66^{\mathrm{a}}$ & 2,63 \\
\hline HAI & $-0,05$ & 0,09 & 2,30 \\
\hline RAC & 0,00 & 0,00 & 1,39 \\
\hline TK & 3,42 & $1,35^{\mathrm{a}}$ & 1,30 \\
\hline URDS & 0,09 & 0,88 & 4,93 \\
\hline TSPDS & $-1,53$ & 1,18 & 5,34 \\
\hline NPKDS & $-0,90$ & 1,05 & 4,33 \\
\hline F & 14,16 & $0,00^{\mathrm{a}}$ & \\
\hline $\mathrm{R} 2$ & 0,40 & & \\
\hline DW & 1,71 & & \\
\hline CI & 21,43 & & \\
\hline
\end{tabular}

Keterangan:

a : signifikan pada taraf uji $1 \%$

b : signifikan pada taraf uji $5 \%$

c : signifikan pada taraf uji $10 \%$

Model ini memiliki asumsi bahwa variable pupuk kandang, biayapestisida dan tenaga kerja antara SRI dan non SRI memiliki dampak yang sama. Oleh karena itu dummy interaksi untuk variable pupuk kandang, biaya pestisida dan tenaga kerja tidak dianalisis.

Beberapa variabel yang signifikan pada tingkat signifikan hingga 10 persen, yaituvariabeldummy Kabupaten Karawang, dummy SRI, dummy Kawasan Tengah, dummy interaksi antara dummy Kabupaten Karawang dan dummy SRI, dummy interaksi antara dummy Kawasan Tengah dan dummy SRI, jumlah pupuk TSP per hektar, jumlah pupuk NPK per hektar, dan jumlah penggunaan tenaga kerja per hektar. Semua variabel memiliki tanda yang sama dengan hipotesis kecuali untuk dummy Karawang. Dummy Karawang memiliki tanda negatif, ini berarti produktivitas padi di Karawang lebih rendah berbanding di Subang.

Tabel4 memperlihatkan bahwa beberapa variable untuk input SRI hampir seluruhnya memiliki nilai positif terhadap produksi padi, kecuali untuk pupuk urea.

Tabel 4. Nilai Koefisien Variabel Input SRI

\begin{tabular}{lc}
\hline Variabel & Koefisien \\
\hline DKDS & 15,22 \\
DS & 1261,91 \\
D1DS & 252,60 \\
D2DS & 103,87 \\
URDS & $-0,46$ \\
TSPDS & 0,27 \\
NPKDS & 0,54
\end{tabular}

Sumber: Hasil analisis

Selanjutnya, Tabel 5 menggambarkan hasil estimasi nilai elastisitas dari masing-masing variabel dengan menggunakan rumus elastisitas $\beta \frac{x_{i}}{Y}$. Tabel ini menunjukkan bahwa nilai skel ekonomi dari kedua pertanian berada pada keadaan decreasing return to scale, karena seluruh nilai elastisitas inputnya kurang dari 1. Nilai elastisitas input seluruh pertanian adalah 0,13 , ini berarti proporsi penambahan input secara bersama-sama maka akan meningkatkan output yang nilainya kurang dari proporsi peningkatan input. Nilai ini sesuai dengan kajian dari Gupta,et.al.(2013) bahwa nilai-nilai elastisitas input dari pertanian di Assam, India. Nilai elastisitas input-input dalam kajian ini memiliki nilai tertinggi sebesar 0,62 (decreasing return to scale). Selain itu, hasil ini juga sesuai dengan kajian Miftachudin (2014) yang menganalisis faktor-faktor yang mempengaruhi produksi padi di Kudus, Indonesia. Berdasarkan hasil Miftachudin, didapati bahwa kondisi usahatani padi di kawasan tersebut berada pada kondisi decreasing return to scale, yaitu sebesar 0,27.

Faroby dan Jamal, Faktor-faktor....|56 
Nilai elastisitas input SRI adalah 0,08 (decreasing return to scale). Ini berarti proporsi penambahan input secara bersama-sama maka akan meningkatkan output yang nilainya kurang dari proporsi peningkatan input. Sesuai dengan kajian Isyanto (2012) tentang usahatani padi SRI di Ciamis, Indonesia. Berasaskan kajian Isyanto, fungsi produksi SRI di Ciamis berada dalam tahap decreasing return to scale.

Tabel 5. Nilai Elastisitas Model 2

\begin{tabular}{ccr}
\hline \multirow{2}{*}{ Variabel } & \multicolumn{2}{c}{ Elastisitas } \\
\cline { 2 - 3 } & Non SRI & SRI \\
\hline UR & $-0,02$ & $-0,006$ \\
TSP & 0,04 & 0,002 \\
NPK & 0,03 & 0,006 \\
HAI & $(0,01)$ & $0,01)$ \\
RAC & 0,00 & 0,00 \\
TK & 0,09 & 0,09 \\
RTS & 0,13 & $0,08^{*}$ \\
\hline
\end{tabular}

Sumber: Hasil analisis

Keterangan:

*) Elastisitas pupuk kandang, biaya pestisida dan tenaga kerja untuk SRI dianggap nilainya sama dengan non SRI

Hasil estimasi skala usaha, yaitu penggunaan pupuk urea untuk SRI dan non SRI berada pada kondisi decreasing returns to scaletetapi tidak signifikan pada taraf uji 10 persen. Nilai elastisitas ini berarti proporsi penambahan penggunaan pupuk urea sebesar 1 persen akan menyebabkan tambahan penurunan output sebesar 0,021 persen. Sementara itu untuk pertanian SRI, jika ada penambahan penggunaan pupuk urea pada pertanian SRI sebesar 1 persen, akan menyebabkan penurunan tambahan output sebesar 0,006 persen. Oleh itu, apabila terus meningkatkan input produksi pupuk urea, maka akan merugikan petani.

Penggunaan input TSP untuk keseluruhan pertanian dan non SRI memiliki nilai positif dan signifikan pada taraf nyata sebesar 1 persen. Nilai ini sesuai dengan hipotesis kajian yaitu semakin meningkat penggunaan TSP maka akan meningkatkan produksi padi. Nilai elastisitas TSP untuk keseluruhan pertanian ialah 0,04 dan SRI ialah 0,002 . Ini berarti jika ada peningkatan penggunaan TSP, maka akan meningkatkan produksi seluruh pertanian sebesar 0,04persen dan SRI ialah 0,002 persen. Selanjutnya untuk NPK, baik untuk seluruh pertanian maupun SRI memiliki nilai positif yang sesuai dengan hipotesis, nilai elastisitas NPK untuk keduanya adalah 0,03 dan 0,006.Ini berarti jika ada peningkatan penggunaan NPK 1 persen untuk kedua-duanya maka akan meningkatkan produksi sebesar 0,03persen untuk seluruh pertanian dan 0,006 persen untuk SRI

Tenaga kerja memiliki nilai positif dan signifikan pada taraf uji 10 persen.Ini sesuai dengan hipotesis, dimana semakin meningkat penggunaan input-input maka produksi pun akan meningkat. Nilai elastisitas input tenaga kerja sesuai dengan kajian yang dilakukan oleh Kusnadi et. al. (2011) terhadap efisiensipertanian padi di beberapa pusat produksi beras di Indonesia, dimana nilai elastisitas untuk variabel ini adalah positif dan tidak elastis, sebesar 0,07 .

Hasil estimasi skala usaha dari kedua pertanian memiliki implikasi apabila terus meningkatkan input, maka akan merugikan petani. Hal ini karena penggunaan input petani tidak sesuai dengan saran pemerintah. Jumlah penggunaan input, terutama untukpupuk kimia yang diberikan oleh petani lebih tinggi dari yang direkomendasikan pemerintah. Penggunan pupuk kimia secara terus menerus pada tanah pertanian menyebabkan tanah kurang responsif terhadap pempupukan. Menurut kajian Pusat Penelitian dan Pengembangan Tanah dan Agroklimat (Puslitbangtanak) Kementerian Republik Indonesia, produktivitas tanah-tanah sawah di Jawa telah mengalami penurunan (levelling off). Ini berarti untuk mendapatkan tingkat produktivitas padi yang sama diperlukan input lebih banyak atau penambahan input yang banyak tidak diimbangi dengan penambahan hasil padi secara proporsional.

\section{SIMPULAN DAN SARAN}

\section{Simpulan}

Faktor-faktor yang signifikan mempengaruhi produksi padi adalah variabel dummy Kabupaten Karawang, dummy SRI, dummy kawasan tengah, dummy interaksi antara dummy Kabupaten Karawang dan dummy SRI, dummy interaksi antara dummy kawasan tengah dan dummy SRI, jumlah pupuk TSP per hektar, jumlah pupuk NPK per hektar, dan jumlah penggunaan tenaga kerja per hektar. Semua variable memiliki tanda yang sama dengan hipotesa kecuali untuk dummy Karawang. Dummy Karawang memiliki tanda negatif, ini berarti hasil padi di Karawang lebih rendah daripada hasil padi di Subang.

Nilai skala ekonomi dari pertanian non SRI dan SRI berada pada tahap decreasing returns to scale, dengan nilai elastisitas input non SRI sebesar 0,13 dan SRI sebesar 0,08. Ini berarti proporsi penambahan input secara bersama-sama yang digunakan pada kedua pertanian lebih kecil berbanding peningkatan output yang diperoleh.

Faroby dan Jamal, Faktor-faktor....|57 


\section{Saran}

Kebiasaan petani melakukan kegiatan pertanian yang menggunakan bahan kimia, maka dalam melakukan SRI pun masih banyak juga yang menggunakan pupuk kimia.Padahal pemerintah memiliki prinsip bahwa SRI merupakan pertanian organik.Oleh itu tidak sedikit petani yang mencampurkan bahan organik dengan bahan kimia. Berdasarkan hal ini, sebaiknya pemerintah memberikan insentif tambahan selain insentif input, seperti insentif memberikan harga premium untuk setiap padi organik yang dihasilkan, kerana saat ini belum ada insentif harga dari pemerintah terhadap hasil pertanian organik yang membedakannya dengan bukan organik.

\section{DAFTAR PUSTAKA}

Darmawan, Astiana. 2007. Uji Keunggulan Sistem Tanam Padi SRI (System Rice Intensification) dalam Rangka Peningkatan Produksi Padi.PPM Kompetitif.LPPM.IPB.

Debertin, D.L. 1986. Agricultural Production Economics. Macmillan Publishing Company, New York.

Doll, P.J dan Orazem, F. 1984.Production Economic Theory with Aplications. Edisi Kedua. Jhon Wiley \& Sons.Kanada.

Gujarati, D. 1990. Ekonometrika Dasar. Penerbit Erlangga. Jakarta.

Isyanto, Agus Yuniawan. 2012. Faktor-Faktor yang Berpengaruh terhadap Produksi pada Usahatani Padi di Kabupaten Ciamis. CAKRAWALA GALUH. Vol. I No. 8 Maret 2012

Makarim, A. K \& Ikhwani. 2013. System of Rice Intensification (SRI) dan Peluang Peningkatan Produksi Padi Nasional. Seminar Puslitbang Tanaman Pangan, Bogor 11 April 2013

Miftachuddin.2014. Analisis Efisiensi FaktorFaktor Produksi Usaha Tani Padi Di Kecamatan Undaan Kabupaten Kudus. Economics Development JournalVol 3 No 1 (2014). Agustus 2014.

Mutakin, J. 2005. Budidaya dan Keunggulan Padi Organik Metode SRI (System of Rice Intensification).Tesis.Pascasarjana. Unpad Bandung.
Mutakin J. 2007 Budidaya dan Keunggulan Padi Organik Metode SRI (System of Rice Intensification), Garut Jawa Barat.

Kusnadi, Nunung, dkk. 2011. Analisis Efisiensi Usahatani Padi di Beberapa Sentra Produksi Padi di Indonesia. Bogor. Volume 29 No.1, Mei 2011

Pemkab Cianjur. 2007. Kepala Negara Ajak Masyarakat Kembangkan Padi SRI Organik.www.cianjur.go.id/content lisilink berita daerah.php? $\underline{\text { Modal }=\text { convert } \text { topdf } \& \text { bid }=198}$

Pusdatin Setjen Kementan. 2014. Statistik Ketenagakerjaan Sektor Pertanian Tahun 2014. Pusat Data dan Sistem Informasi Pertanian.Sekretariat Jenderal Kementerian Pertanian Republik Indonesia. Jakarta

Setjen Deptan. 2007. Presiden SBY minta SRI dikembangkan.http://setjen.deptan. go.id/berita/detail.php?id=151

Sirajudin. 2006. The Adoption of SRI Method in Desa Cibadak, Kabupaten Sukabumi, Indonesia. Personal Communication on March 15, 2006.

Soekartawi. 1990. Teori Ekonomi Produksi. PT RajaGrafindo Persada. Jakarta

Upboff, N. 2008.The system of rice intensification (SRI) as a system of agricultural innovation.Jurnal Tanah dan Lingkungan, Vol. 10 No.1, April 2008:27-40

Uphoff, N. 2002.Agroecological Innovations; Increasing Food Production with Participatory Development.Earthscan. London 